\title{
Pengaruh Struktur Modal, Struktur Kepemilikan, Faktor Teknikal Terhadap Profitabilitas dengan Total Pendapatan Sebagai Variabel Moderasi Pada Sub Sektor Perkebunan Di Bursa Efek Indonesia Periode 2015-2018
}

\author{
Yunan Surono $^{1 *}$, Amilia Paramita $S^{2}$, Ali Akbar ${ }^{3}$ \\ ${ }^{1,2,3}$ Fakultas Ekonomi Universitas Batanghari \\ *Correspondence email: suronoyunan@gmail.com
}

\begin{abstract}
This research aims to look at the influence of capital structure, ownership structure, technical factors on profitability with total income as a moderation variable in the plantation sub-sector on the Indonesia Stock Exchange period 2014 - 2018. This research, using secondary data, is data obtained from official reports issued by issuers, institutions and competent authorities. This study used Smart PLS 3.0 where all latent variables in this study had reflective indicators. The results showed that 1). capital structure has no effect on profitability, and has a negative (debilitating) direction. 2). The ownership structure has no effect on profitability, but has a positive direction (strengthening). 3). Technical factors have no effect on profitability, but have a positive direction (strengthening) 4). Moderation variables i.e. total income are not able to moderate the relationship between capital structure variables to profitability variables, with positive direction (strengthening). 5). Total revenue variables are unable to moderate the relationship between ownership structure variables to profitability variables in a positive (corroborating) direction. 6). Total revenue variables are unable to moderate the relationship between technical factor variables to profitability variables in a positive (strengthening) direction.
\end{abstract}

Keyword: capital structure; ownership structure; technical factors; Profitability

\section{Pendahuluan}

Kinerja keuangan suatu perusahaan tergambar dari laporan keuangannya, yang terdiri dari neraca, laporan rugi laba, laporan perubahan modal, laporan arus kas dan catatan atas laporan keuangan. Kinerja keuangan dapat dianalisis memalui berbagai cara dan metode guna memperoleh gambaran, apakah perusahaan tersebut mempunyai kinerja yang baik, sedang atau buruk. Salah satu cara yang digunakan adalah analisis rasio keuangan antara lain rasio likuiditas, aktivitas, profitabilitas, solvabilitas dan nilai pasar (Kasmir, 2014). Penelitian ini akan dilakukan pada perusahaan emiten sub sektor perkebunan yang ada di Bursa Efek Insonesia. Indonesia sebagai salah satu negara penghasil terbesar produk kelapa sawit dan turunannya di pasar dunia, faktor naik turunnya harga produk kelapa sawit dan turunannnya yang akan mempengaruhi besarnya penjualan dan tingkat keuntungan yang diperoleh bagi investor, serta kinerja masing-masing perusahaan emiten yang mempunyai perbedaan yang cukup signifikan. Penelitian ini menggunakan variabel struktur modal dalam perusahaan yang ada dalam rasio solvabilitas yakni berupa Debt to Asset Ratio (DAR) dan Debt to Equity Ratio (DER).Data awal penelitian yang diperoleh, untuk menghitung variabel struktur modal dengan indikator Debt to Asset Ratio (DAR) dan Debt to Equity Ratio (DER) diperlukan yakni berupa data total aset, total hutang dan total modal yang dipublikasikan oleh masing-masing perusahaan emiten.

Penelitian ini, juga menggunakan variabel struktur kepemilikan, Jahera dan Auburn (1996) dalam saidi (2004), mengemukakan struktur kepemilikan (ownership structure) yaitu perbandingan antara jumlah saham yang dimiliki oleh orang dalam (insiders) dengan jumlah saham yang dimiliki oleh investor. Penelitian ini menggunakan struktur kepemilikan perusahaan dengan menggunakan indikator berupa kepemilikan institusional, kepemilikan publik dan kepemilikan manajerial. Penelitian ini juga menggunakan variabel bebas berupa faktor teknikal dengan menggunakan indikator berupa volume perdagangan, frekuensi perdagangan dan nilai perdagangan. Volume perdagangan saham merupakan jumlah lembar saham yang diperdagangkan pada hari tertentu (Halim dan Hidayat, 2000). Perdagangan suatu saham yang aktif, yaitu dengan volume perdagangan yang besar, menunjukkan bahwa saham tersebut diminati oleh para investor yang berarti saham tersebut cepat diperdagangkan. Frekuensi perdagangan yang merupakan jumlah terjadinya transaksi perdagangan saham perusahaan emiten tersebut. Silviyani (2014), mengemukakan bahwa saham yang memiliki frekuensi perdagangan besar diduga dipengaruhi transaksi saham yang sangat aktif, karena banyaknya minat investor, sehingga akan diketahui bahwa saham tersebut diminati investor atau tidak. Nilai perdagangan yang merupakan seluruh nilai dari kegiatan jual atau beli pada saham perusahaan emiten. (Adisetiawan dan Surono, 2016)

Penelitian ini, menggunakan variabel terikat berupa profitabilitas dengan menggunakan indikator berupa Return On Asset, Return On Equity, Operating Profit Margin, Gross Profit Margin dan Net Profit Margin. Data awal yang diperoleh dalam variabel profitabilitas. Data yang diperlukan untuk melengkapi indikator profitabilitas antaralain 
Yunan Surono et al, Pengaruh Struktur Modal, Struktur Kepemilikan, Faktor Teknikal Terhadap Profitabilitas dengan Total Pendapatan Sebagai Variabel Moderasi Pada Sub Sektor Perkebunan Di Bursa Efek Indonesia Periode 2015-2018

total asset, total utang, total ekuitas, laba kotor, laba operasi dan laba bersih yang diperoleh dari publikasi masingmasing perusahaan emiten. Tujuan penelitian ini adalah menganalisis pengaruh faktor teknikal terhadap profitabilitas dengan total pendapatan sebagai pemoderasi pada kelompok saham sub sektor perkebunan di Bursa Efek Indonesia periode $2014-2018$.

\section{Tinjauan Literatur}

Investor menanamkan dananya di pasar modal dengan harapan memperoleh keuntungan semaksimal mungkin. Keuntungan diperoleh investor atas dananya yang diinvestasikan pada saham berupa bagian laba (dividen) dan selisih harga jual saham dengan harga belinya (capital gain). Keuntungan dari dividen hanya diperoleh setiap tahun, sementara keuntungan dari capital gain diperoleh setiap kali terjadi transaksi jual beli saham. Pelaku pasar modal lebih banyak yang mengharapkan keuntungan dari perdagangan saham, karena bisa diperoleh setiap saat. Harga saham dapat berubah setiap saat, dan perubahan harga tersebut secara teoritik dipengaruhi oleh dua faktor, yakni faktor fundamental dan faktor teknikal. Harga saham cukup sensitif terhadap berbagai isu dan kasus yang terjadi diluar perusahaan. (adisetiawan dan Atikah, 2018).

Analisa fundamental menurut Indonesia Stock Exchange (IDX) merupakan suatu analisa yang mempelajari hal-hal yang berhubungan dengan kondisi keuangan suatu perusahaan dengan tujuan untuk mengetahui sifat-sifat dasar dan karakteristik operasional dari perusahaan publik. Faktor fundamental ini bisa dilihat dari laporan keuangan yang diterbitkannya, dan dari laporan keuangan emiten, maka dapat dilihat kinerja keuangannya, baik dari segi kemampuan menghasilkan keuntungan (profitabilitas), kemampuan membayar hutang (likuiditas), struktur modalnya (leverage), maupun tingkat efisiensi dan efektifitasnya dalam mengelola kekayaannya (aktivitas) maupun kinerja pasarnya. Dalam penelitian ini, profitabilitas diproksikan dengan return on asset (ROA), return on equity (ROE), operating profit margin (OPM), gross profit margin (GPM), dan net profit margin (NPM) struktur modal diproksikan dengan debt to equity ratio (DER) dan debt to asset ratio (DAR), aktivitas diproksikan dengan total asset turnover (TATO).

Struktur kepemilikan saham adalah proporsi kepemilikan institusional, kepemilikan publik, dan kepemilikan manajerial, merupakan suatu mekanisme untuk mengurangi konflik antara manajemen dengan pemegang saham. Pengelolaan suatu perusahaan sebaiknya dilakukan oleh para professional, pemisahan antara pemilik perusahaan dan manajer perusahaan akan mampu meningkatkan kinerja perusahaan. Pemilik atau pemegang saham adalah pihak yang menyertakan modal kedalam perusahaan, sedangkan manajer adalah pihak yang ditunjuk pemilik dan diberi kewenangan mengambil keputusan dalam mengelola perusahaan, dengan harapan manajer bertindak sesuai dengan kepentingan pemilik. Kepemilikan saham oleh pihak manajemen akan menjadikan nilai perusahaan meningkat karena manajemen melaksanakan dan selalu mengawasi perkembangan perusahaan sekaligus memperhitungkan kebijakan yang terbaik. Semakin besar kepemilikan saham oleh manajerial, maka manajerial akan bekerja lebih proaktif dalam mewujudkan kepentingan pemegang saham dan akan meningkatkan kepercayaan, kemudian nilai perusahaan akan naik.

Faktor teknikal adalah faktor-faktor yang berasal dari luar perusahaan yang mempengaruhi harga saham perusahaan. Analisis teknikal atau technical analysis adalah pendekatan investasi dengan cara mempelajari data historis dari harga saham serta menghubungkannya dengan perdagangan yang terjadi dan kondisi ekonomi pada saat itu. Ada beberapa variabel faktor teknikal yang mempengaruhi harga saham seperti suku bunga, tingkat inflasi, nilai kurs valuta asing, kebijakan ekonomi, dan lainnya. Faktor teknikal ini ada yang terjadinya sepanjang waktu seperti volume perdagangan, frekuensi perdagangan dan nilai perdagangan. Profitabilitas adalah kemampuan seberapa tingkat keuntungan yang dapat diperoleh oleh perusahaan, semakin besar tingkat keuntungan semakin baik manajemen dalam mengelola perusahaan. Penelitian ini, menggunakan return on asset (ROA), return on equity (ROE), operating profit margin (OPM), gross profit margin (GPM), dan net profit margin (NPM). Kegiatan penjualan baik barang maupun jasa yang dilakukan oleh perusahaan akan berdampak pada pendapatan yang diperoleh perusahaan yang kemudian akan berdampak pada laba atau rugi bagi perusahaan. Pendapatan adalah arus masuk atau penyelesaian (atau kombinasi keduanya) dari pengiriman atau produksi barang, memberikan jasa atau melakukan aktivitas lain yang merupakan aktivitas utama atau aktivitas centra yang sedang berlangsung.

Hipotesis dalam penelitian ini diduga faktor teknikal berpengaruh secara positif dan signifikan terhadap profitabilitas dengan total pendapatan sebagai pemoderasi pada sub sektor perkebunan di Bursa Efek Indonesia periode $2014-2018$.

\section{Metode}

Penelitian ini menggunakan analisis kausalitas SEM (Structural Equation Modeling) berbasis component atau variance yang terkenal dengan Partial Least Square (PLS), dengan menggunakan software Smart PLS 3.0. Keunggulan metode ini adalah tidak memerlukan asumsi dan dapat diestimasi dengan jumlah sampel yang relatif 
Yunan Surono et al, Pengaruh Struktur Modal, Struktur Kepemilikan, Faktor Teknikal Terhadap Profitabilitas dengan Total Pendapatan Sebagai Variabel Moderasi Pada Sub Sektor Perkebunan Di Bursa Efek Indonesia Periode 2015-2018

kecil. (Haryono, 2017). Penelitian ini untuk menganalisis hubungan dari pengaruh struktur modal (X1), struktur kepemilikan (X2) dan faktor teknikal (X3) terhadap profitabilitas (Y) dengan total pendapatan (Z) sebagai variabel moderasi.

Adapun penelitian ini akan mengikuti langkah-langkah pengujian model penelitian berbasis PLS, (Yamin, 2011) sebagai berikut:

1. Merancang Model Struktural (inner model), pada tahap ini, peneliti memformulasikan model hubungan antar konstruk.

2. Merancang Model Struktural (outer model), pada tahap ini, peneliti mendefinisikan dan menspesifikasikan hubungan antar konstruk laten dengan indikatornya apakah bersifat reflektif atau formatif.

3. Mengkonstruksi diagram jalur, yang berfungsi untuk memvisualisasikan hubungan antar indikator dengan konstruknya serta antara konstruk yang akan mempermudah peneliti untuk melihat model secara keseluruhan. Hubungan antar konstruk seperti pada Gambar 2.

\section{Gambar 1 \\ Diagram Jalur Penelitian}

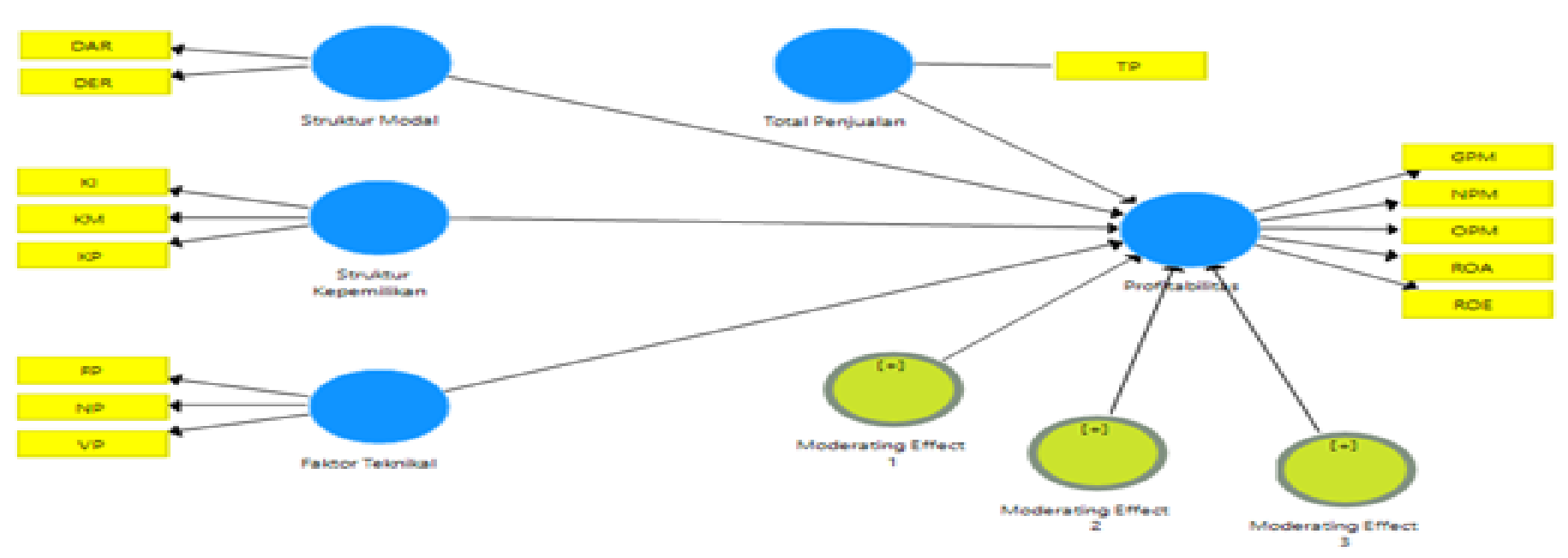

4. Estimasi Model, pada tahap ini ada tiga skema pemilihan weighting dalam proses estimasi model yakni factor weighting scheme, centroid weighting scheme dan path weighting scheme.

5. Goodness of fit atau evaluasi model meliputi evaluasi model pengukuran dan evaluasi model struktural.

6. Pengujian hipotesis dan interpretasi

\section{Hasil}

\section{Tabel 1}

Nilai Construct Reliability and Validity PLS Algorithm Keenam

\begin{tabular}{|l|r|r|r|r|}
\hline & Cronbach's Alpha & rho_A & Composite Reliability & Average variance Extracted \\
\hline Faktor Teknikal & 1.000 & 1.000 & 1.000 & 1.000 \\
\hline Moderating Effect 1 & 1.000 & 1.000 & 1.000 & 1.000 \\
\hline Moderating Effect 2 & 1.000 & 1.000 & 1.000 & 1.000 \\
\hline Moderating Effect 3 & 1.000 & 1.000 & 1.000 & 1.000 \\
\hline Profitabilitas & 0.902 & 0.939 & 0.928 & 0.724 \\
\hline Struktur Kepemilikan & 1.000 & 1.000 & 1.000 & 1.000 \\
\hline Struktur Modal & 1.000 & 1.000 & 1.000 & 1.000 \\
\hline Total Penjualan & 1.000 & 1.000 & 1.000 & 1.000 \\
\hline
\end{tabular}

Sumber : data hasil PLS, 2020.

Berdasarkan Tabel 1. terlihat nilai Cronbach's Alpha dan Average Variance Extracted, mempunyai nilai diatas 0,7 dan 0,5., hal tersebut menggambarkan bahwa uji reliabilitas telah memenuhi syarat atau telah memiliki 
Yunan Surono et al, Pengaruh Struktur Modal, Struktur Kepemilikan, Faktor Teknikal Terhadap Profitabilitas dengan Total Pendapatan Sebagai Variabel Moderasi Pada Sub Sektor Perkebunan Di Bursa Efek Indonesia Periode 2015-2018

kelayakan data. Hasil perhitungan (calculate) PLS algorithm keenam dengan menggunakan software Smart PLS 3.0 terlihat pada gambar berikut:

\section{Gambar 2}

\section{Model penelitian keenam.}

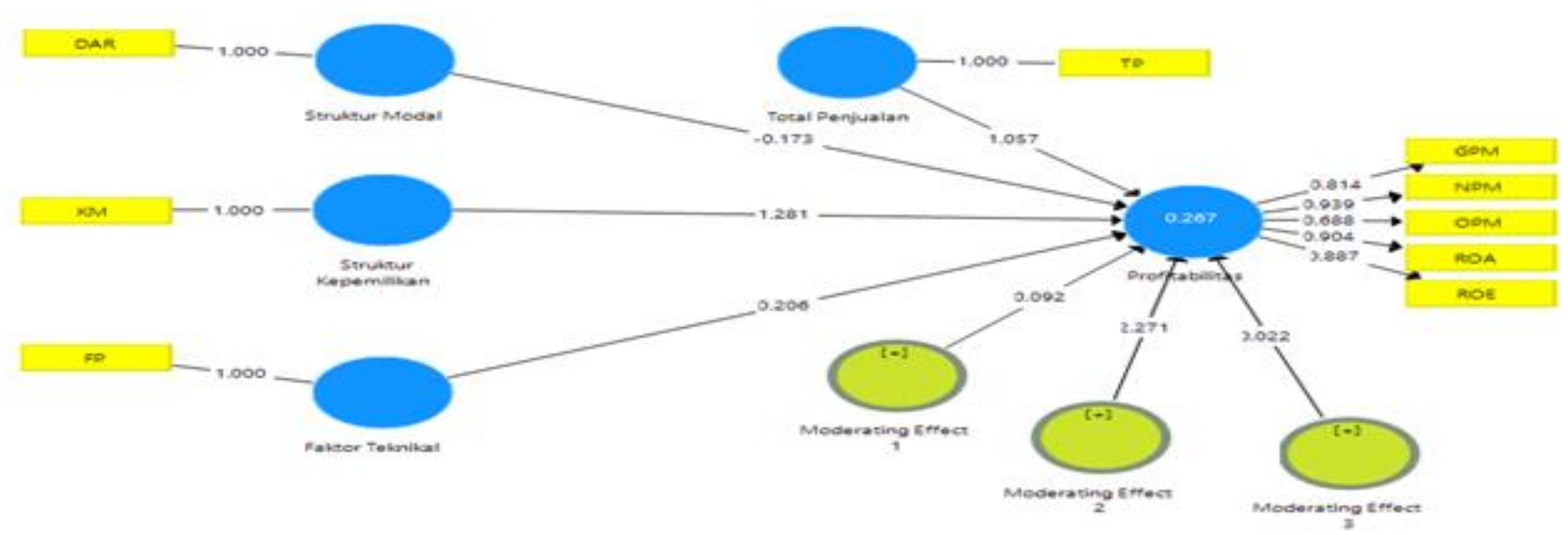

Indikator pada suatu konstruk yang mempunyai loading factor pada konstruk yang dibentuknya. Nilai outer loading pada model keenam dapat dilihat pada tabel 2berikut:

Tabel 2

Nilai Outer Loading PLS Algorithm Keenam

\begin{tabular}{|c|c|c|c|c|c|c|c|c|}
\hline & Faktor Teknikal & Moderating Effect 1 & Moderating Effect 2 & Moderating Effect 3 & Profitabilitas & Struktur Kepemilikan & Struktur Modal & Total Penjualan \\
\hline$\frac{D A R}{P P}$ & & & & & & & 1.000 & \\
\hline FP & 1.000 & & & & & & & \\
\hline $\begin{array}{l}\text { Faktor Tehrikal'Total Perinualan } \\
\text { GPM }\end{array}$ & & & & 0.852 & & & & \\
\hline GPM & & & & & 0.814 & & & \\
\hline $\mathrm{KM}$ & & & & & & 1.000 & & \\
\hline NPM & & & & & 0.939 & & & \\
\hline OPM & & & & & 0.688 & & & \\
\hline ROA & & & & & 0.904 & & & \\
\hline ROE & & & & & 0.887 & & & \\
\hline Struktur Kepemilikan ${ }^{*}$ Total Penjualan & & & 0.696 & & & & & \\
\hline Struktur Modal ${ }^{\text {Totota1 Penjualan }}$ & & 0.771 & & & & & & \\
\hline & & & & & & & & 1.000 \\
\hline
\end{tabular}

Sumber : data hasil PLS, 2020.

Berdasarkan perhitungan Construct Reliability and Validity pada Tabel 2, maka nilai Cronbach's Alpha semua indikator pada variabel struktur modal, struktur kepemilikan dan factor teknikal telah memenuhi uji prasyarat yakni mempunyai nilai lebih besar dari 0,7 dan nilai Average Variance Extracted lebih besar dari 0,5. Dengan demikian indikator-indikator tersebut merupakan indikator yang reliabel dan valid sebagai indikator yang merefeksikan variabel penelitian ini. Langkah selanjutnya kita akan melihat besarnya Collinearity Statistic (VIF), yang akan memberikan gambaran tentang apakah data tersebut terjadi multikolinearitas atau tidak.

Tabel 3. Nilai outer loading VIF / Variance Inflation Factors (outer VIF values) menunjukkan, indikator NPM, ROA dan ROE terjadi multikolinearitas dimana pada variabel tersebut mempunyai nilai lebih dari 5, pada Smart PLS (warna merah menunjukkan terjadi multikolinearitas, warna hijau menunjukkan layak / tidak terjadi multikolinearitas, dan warna hitam berarti masih bisa diterima). Nilai VIF pada SPSS biasanya digunakan angka kurang dari 10), hal tersebut menunjukkan bahwa semua indikator tidak terjadi multikolinearitas.

Tabel 3

Nilai VIF (Variance Inflation Factors)

\begin{tabular}{|l|r|}
\hline & VIF (Variance Inflation Factors) \\
\hline DAR & $\mathbf{1 . 0 0 0}$ \\
\hline FP & $\mathbf{1 . 0 0 0}$ \\
\hline Faktor Teknikal*Total Penjualan & $\mathbf{1 . 0 0 0}$ \\
\hline GPM & $\mathbf{3 . 2 0 8}$ \\
\hline KM & $\mathbf{1 . 0 0 0}$ \\
\hline NPM & $\mathbf{7 . 2 4 2}$ \\
\hline OPM & $\mathbf{2 . 5 8 0}$ \\
\hline
\end{tabular}


Yunan Surono et al, Pengaruh Struktur Modal, Struktur Kepemilikan, Faktor Teknikal Terhadap Profitabilitas dengan Total Pendapatan Sebagai Variabel Moderasi Pada Sub Sektor Perkebunan Di Bursa Efek Indonesia Periode 2015-2018

\begin{tabular}{|l|r|}
\hline ROA & $\mathbf{8 . 0 9 2}$ \\
\hline ROE & $\mathbf{9 . 1 9 4}$ \\
\hline Struktur Kepemilikan *Total Penjualan & $\mathbf{1 . 0 0 0}$ \\
\hline Struktur Modal *Total Penjualan & $\mathbf{1 . 0 0 0}$ \\
\hline TP & $\mathbf{1 . 0 0 0}$ \\
\hline
\end{tabular}

Sumber : data hasil PLS, 2020.

Tabel 4

Nilai inner loading PLS algorithm keenam

\begin{tabular}{|c|c|c|c|c|c|c|c|c|}
\hline & Faktor Teknikal & Moderating Effect 1 & Moderating Effect 2 & Moderating Effect 3 & Profitabilitas & Struktur Kepemilikan & Struktur Modal & Total Penjualan \\
\hline Faktor Teknikal & & & & & 2.115 & & & \\
\hline Moderating Effect 1 & & & & & 4.065 & & & \\
\hline Moderating Effect 2 & & & & & 20.543 & & & \\
\hline Moderating Effect 3 & & & & & 4.196 & & & \\
\hline \multicolumn{9}{|l|}{ Profitabilitas } \\
\hline Struktur Kepemilikan & & & & & 18.932 & & & \\
\hline Struktur Modal & & & & & 2.660 & & & \\
\hline Total Penjualan & & & & & 8.426 & & & \\
\hline
\end{tabular}

Sumber : data hasil PLS, 2019.

Nilai inner loading VIF (inner VIF values) menunjukkan, indikator Moderating Effect 2, Struktur Kepemilikan dan Total Penjualan terjadi multikolinearitas dimana pada variabel tersebut mempunyai nilai lebih dari 5, pada Smart PLS termasuk indikator yang tidak layak, sedangkan warna hijau menunjukkan bahwa indikator adalah layak yakni variabel Faktor Teknikal dan variabel Struktur Modal serta warna hitam menunjukkan bahwa indicator tersebut masih dapat diterima yakni variabel indikator Moderating Effect 1 dan indikator Moderating Effect 3. Langkah selanjutnya kita akan melakukan perhitungan (calculate) dengan melakukan Bootstraping.

\section{Gambar 3}

Nilai Bootstraping Model Keenam

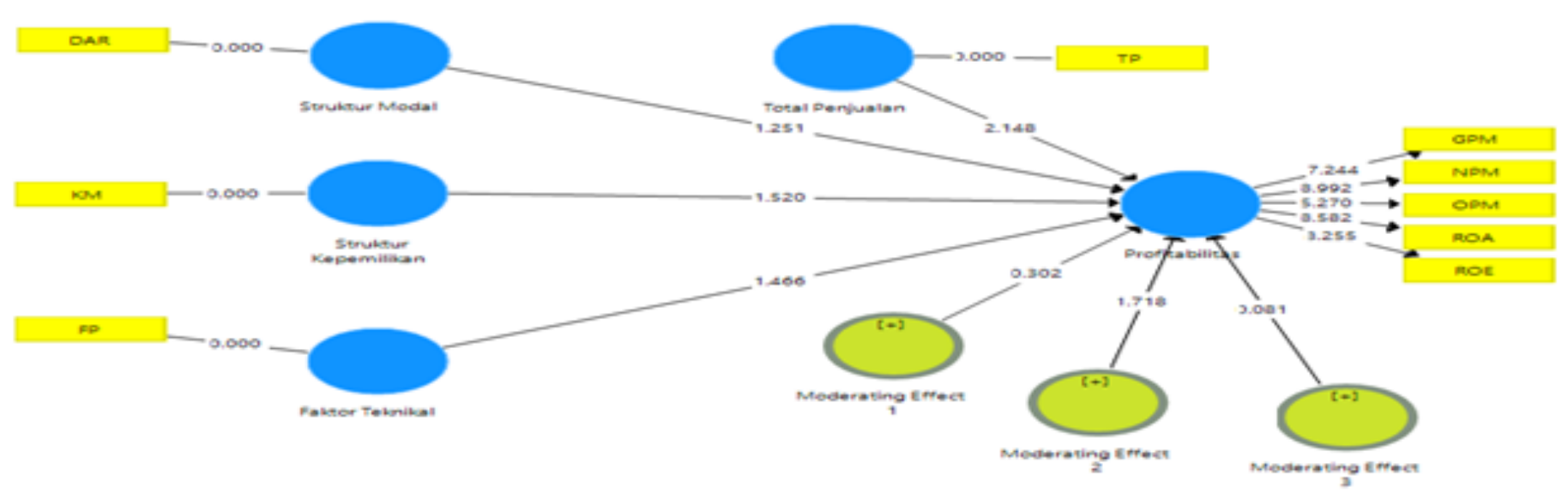

Hasil bootstraping juga menghasilkan tabel result for outer loadings. Tabel ini menggambarkan kemampuan merefleksikan dan signifikansi indikator terhadap variabelnya. Nilai outer loading pada model keenam dapat dilihat pada Tabel 5

Koefisien Jalur (path coefficients)

Tabel 5

Nilai Koeffisien Jalur (Path Coefficients) Hasil Bootstraping

\begin{tabular}{|c|c|c|c|c|c|}
\hline & Original Sample $(\mathbf{O})$ & Sample M ean (M) & Standard Deviati On (ST DEV) & T Statistics ([O/STDE V]) & P Values \\
\hline Faktor teknikal $>$ Profitabilitas & 0.206 & 0.230 & 0.141 & 1.466 & 0.143 \\
\hline Moderating Effect $1->$ Profitabilitas & 0.092 & 0.122 & 0.304 & 0.302 & 0.763 \\
\hline Moderating Effect $2->$ Profitabilitas & 2.271 & 2.428 & 1.322 & 1.718 & 0.086 \\
\hline Moderating Effect $3->$ Profitabilitas & 0.022 & 0.065 & 0.276 & 0.081 & 0.935 \\
\hline Struktur Kepemilikan -> Profitabilitas & 1.281 & 1.384 & 0.843 & 1.520 & 0.129 \\
\hline Struktur Modal $->$ Profitabilitas & -0.173 & -0.155 & 0.139 & 1.251 & 0.212 \\
\hline Total Penjualan $\rightarrow$ Profitabilitas & 1.057 & 1.162 & 0.492 & 2.148 & 0.032 \\
\hline
\end{tabular}

Sumber : data hasil PLS, 2019. 
Guna mengetahui besarnya pengaruh antar variabel dapat diketahui dari kolom original sample dan untuk melihat tingkat signifikasi dapat diketahui dari kolom T statistics. Menurut Ghozali (2013), nilai $t$-stat yang berada diatas nilai 1,96 menunjukkan pengaruh yang signifikan dari masing-masing hipotesis. Selain itu untuk dapat mengetahui besarnya pengaruh antar variabel dapat diketahui juga dari besarnya $P$ values, jika nilai $P$ values lebih kecil (kurang) dari 0,05 atau sebesar 5\% maka hubungan antar variabel tersebut dikatakan berpengaruh, demikian juga jika nilai $\mathrm{P}$ values lebih besar (diatas) 0,05 maka hubungan antar variabel dikatakan tidak berpengaruh. Hasil perhitungan berdasarkan tabel 5 . tersebut menunjukkan bahwa hanya variabel total penjualan yang berpengaruh terhadap profitabilitas.

\section{Pengujian Hipotesis}

Hasil pengujian hipotesis dengan berdasarkan Tabel 5 tersebut sabagai berikut:

1) Pengujian hipotesis pertama

Hipotesis pertama dalam penelitian ini adalah "Diduga struktur modal berpengaruh secara positif dan signifikan terhadap profitabilitas pada sub sektor perkebunan di Bursa Efek Indonesia periode 2014 - 2018". Pengujian hipotesis pertama variabel $\mathrm{X} 1$ yakni struktur modal tidak berpengaruh terhadap variabel Y yakni profitabilitas, karena mempunyai nilai $\mathrm{P}$ values sebesar 0,212 ., dimana nilai $\mathrm{P}$ values tersebut lebih besar dari 0.05 atau lebih besar dari 5\%. Hal ini menunjukkan tidak terdapat cukup bukti empiris untuk menerima hipotesis pertama. Dengan demikian disimpulkan bahwa struktur modal tidak berpengaruh terhadap profitabilitas, tetapi mempunyai arah negatif (melemahkan) yang terlihat pada nilai original sample (O) yakni sebesar -0,173.

2) Pengujian hipotesis kedua

Hipotesis kedua dalam penelitian ini adalah "Diduga struktur kepemilikan berpengaruh secara positif dan signifikan terhadap profitabilitas pada pada sub sektor perkebunan di Bursa Efek Indonesia periode 2014 - 2018. Pengujian hipotesis kedua variabel X2 yakni struktur kepemilikan tidak berpengaruh terhadap variabel Y yakni profitabilitas, karena mempunyai nilai $\mathrm{P}$ values sebesar 0,129 ., dimana nilai $\mathrm{P}$ values tersebut lebih dari 0.05 atau lebih besar dari 5\%. Hal ini menunjukkan tidak terdapat cukup bukti empiris untuk menerima hipotesis kedua. Dengan demikian disimpulkan bahwa struktur kepemilikan tidak berpengaruh terhadap profitabilitas, tetapi mempunyai arah yang positif (menguatkan) yang terlihat pada nilai original sample (O) yakni sebesar 1,281.

3) Pengujian hipotesis ketiga

Hipotesis ketiga dalam penelitian ini adalah "Diduga faktor teknikal berpengaruh secara positif dan signifikan terhadap profitabilitas pada sub sektor perkebunan di Bursa Efek Indonesia periode 2014 - 2018.". Pengujian hipotesis ketiga variabel X3 yakni faktor teknikal tidak berpengaruh terhadap variabel Y yakni profitabilitas, karena mempunyai nilai $\mathrm{P}$ values sebesar 0,143 ., dimana nilai $\mathrm{P}$ values tersebut lebih dari 0.05 atau lebih besar dari $5 \%$. Hal ini menunjukkan tidak terdapat cukup bukti empiris untuk menerima hipotesis ketiga. Dengan demikian disimpulkan bahwa faktor teknikal tidak berpengaruh terhadap profitabilitas, tetapi mempunyai arah yang positif (menguatkan) yang terlihat pada nilai original sample (O) yakni sebesar 0,206.

4) Pengujian hipotesis keempat

Hipotesis keempat dalam penelitian ini adalah "Diduga struktur modal berpengaruh secara positif dan signifikan terhadap profitabilitas dengan total pendapatan sebagai pemoderasi pada sub sektor perkebunan di Bursa Efek Indonesia periode 2014 - 2018". Pengujian hipotesis keempat, dimana variabel moderasi Z yakni total pendapatan berpengaruh terhadap variabel $\mathrm{Y}$ yakni profitabilitas, karena mempunyai nilai $\mathrm{P}$ values sebesar 0,032 ., dimana nilai $\mathrm{P}$ values tersebut kurang dari 0,05 atau kurang dari 5\%. Variabel moderating effect 1 (ME 1), tidak berpengaruh terhadap variabel Y yakni profitabilitas, karena mempunyai nilai P values sebesar 0,763., atau sebesar 76,3\% , dimana nilai $\mathrm{P}$ values tersebut lebih besar dari 0.05 atau lebih dari $5 \%$.

Dengan demikian disimpulkan bahwa variabel $\mathrm{Z}$ yakni total pendapatan tidak mampu memoderasi hubungan antara variabel $\mathrm{X} 1$ yakni struktur modal dengan variabel $\mathrm{Y}$ yakni profitabilitas, dengan arah positif (menguatkan) seperti terlihat pada nilai original sample $(\mathrm{O})$ sebesar 0,092., yang berarti jika nilai $Z$ semakin kecil (mendekati 0 ) maka akan melemahkan hubungan variabel X1 terhadap variabel $\mathrm{Y}$, demikian juga sebaliknya jika nilai $\mathrm{Z}$ semakin besar (mendekati 1) maka akan menguatkan hubungan variabel X1 terhadap variabel Y. Hal ini menunjukkan tidak terdapat cukup bukti empiris untuk menerima hipotesis keempat atau hipotesis ditolak. Dengan demikian disimpulkan bahwa variabel $\mathrm{Z}$ yakni total pendapatan tidak memoderasi hubungan antara variabel struktur modal (X1) dengan variabel $\mathrm{Y}$ yakni profitabilitas dan mempunyai arah positif (menguatkan) pengaruhnya terhadap profitabilitas, yang terlihat pada nilai original sample (O) yakni sebesar 0,092.

5) Pengujian hipotesis kelima

Hipotesis kelima dalam penelitian ini adalah "Diduga struktur kepemilikan berpengaruh secara positif dan signifikan terhadap profitabilitas dengan total pendapatan sebagai pemoderasi pada sub sektor perkebunan di Bursa 
Efek Indonesia periode 2014 - 2018". Pengujian hipotesis kelima, dimana variabel moderasi Z yakni total pendapatan berpengaruh terhadap variabel Y yakni profitabilitas, karena mempunyai nilai P values sebesar 0,032., dimana nilai $\mathrm{P}$ values tersebut kurang dari 0,05 atau kurang dari 5\%. Variabel moderating effect 2 (ME 2) tidak berpengaruh terhadap variabel $\mathrm{Y}$ yakni profitabilitas, karena mempunyai nilai $\mathrm{P}$ values sebesar 0,086 ., atau sebesar $8,6 \%$, dimana nilai P values tersebut lebih besar dari 0.05 atau lebih besar dari 5\%. Dengan demikian disimpulkan bahwa variabel $\mathrm{Z}$ yakni total pendapatan tidak mampu memoderasi hubungan antara variabel $\mathrm{X} 2$ yakni struktur kepemilikan dengan variabel Y yakni profitabilitas dengan arah positif (menguatkan) seperti terlihat pada nilai original sample (O) sebesar 2,271., yang berarti jika nilai $\mathrm{Z}$ semakin besar (mendekati 1) maka akan menguatkan hubungan variabel X2 terhadap variabel $\mathrm{Y}$, demikian juga sebaliknya jika nilai Z semakin kecil (mendekati 0 ) maka akan melemahkan hubungan variabel X2 terhadap variabel Y. Hal ini menunjukkan tidak terdapat cukup bukti empiris untuk menerima hipotesis kelima. Dengan demikian disimpulkan bahwa variabel $\mathrm{Z}$ yakni total pendapatan tidak mampu memoderasi hubungan antara variabel struktur kepemilikan (X2) dengan variabel $\mathrm{Y}$ yakni profitabilitas dan mempunyai arah positif (menguatkan) pengaruhnya terhadap profitabilitas, yang terlihat pada nilai original sample $(\mathrm{O})$ yakni sebesar 2,271.

6) Pengujian hipotesis keenam

Hipotesis keenam dalam penelitian ini adalah "Diduga faktor teknikal berpengaruh secara positif dan signifikan terhadap profitabilitas dengan total pendapatan sebagai pemoderasi pada sub sektor perkebunan di Bursa Efek Indonesia periode 2014 - 2018. Pengujian hipotesis keenam, dimana variabel moderasi Z yakni total pendapatan berpengaruh terhadap variabel $Y$ yakni profitabilitas, karena mempunyai nilai $P$ values sebesar 0,032 ., dimana nilai $\mathrm{P}$ values tersebut kurang dari 0,05 atau kurang dari 5\%. Variabel moderating effect 3 (ME 3) tidak berpengaruh terhadap variabel $\mathrm{Y}$ yakni profitabilitas, karena mempunyai nilai $\mathrm{P}$ values sebesar 0,935 ., atau sebesar 93,5\% , dimana nilai $\mathrm{P}$ values tersebut lebih besar dari 0.05 atau lebih besar dari 5\%. Dengan demikian disimpulkan bahwa variabel $\mathrm{Z}$ yakni total pendapatan tidak mampu memoderasi hubungan antara variabel X3 yakni faktor teknikal dengan variabel $Y$ yakni profitabilitas dengan arah positif (menguatkan) seperti terlihat pada nilai original sample (O) sebesar 0,022., yang berarti jika nilai $\mathrm{Z}$ semakin besar (mendekati 1) maka akan menguatkan hubungan variabel X3 terhadap variabel $Y$, demikian juga sebaliknya jika nilai Z semakin kecil (mendekati 0) maka akan melemahkan hubungan variabel X3 terhadap variabel Y. Hal ini menunjukkan tidak terdapat cukup bukti empiris untuk menerima hipotesis keenam. Dengan demikian disimpulkan bahwa variabel Z yakni total pendapatan tidak mampu memoderasi hubungan antara variabel faktor teknikal (X3) dengan variabel Y yakni profitabilitas dan mempunyai arah positif (menguatkan) pengaruhnya terhadap profitabilitas, yang terlihat pada nilai original sample (O) yakni sebesar 0,022 .

\section{Pengujian kelayakan model (goodness of fit)}

Pengujian terhadap nilai $R$-square sebagai hasil uji goodness of fit model dilihat dari besaran angka nilai $R$ square, yang dapat dilihat di dalam tabel $R$-square dari hasil running calculate model dan diperoleh angka sebesar 0,267 atau sebesar $26,7 \%$. Angka tersebut memperlihatkan bahwa besarnya pengaruh keragaman data yang dapat dijelaskan oleh model tersebut adalah sebesar $26,7 \%$., sisanya sebesar 73,3\% dijelaskan oleh variabel lain yang belum terkandung dalam model tersebut dan termasuk error. Hasil tersebut memberikan makna bahwa model penelitian ini merupakan model yang tergolong lemah, Ghozali (2013) seperti pada kriteria penilian PLS pada Tabel 5

Berdasarkan uji hipotesis dapat diketahui bahwa:

1) Pengujian hipotesis pertama, variabel $X 1$ yakni struktur modal tidak berpengaruh terhadap variabel $Y$ yakni profitabilitas, karena mempunyai nilai $\mathrm{P}$ values sebesar 0,212 , dimana nilai $\mathrm{P}$ values tersebut lebih besar dari 0.05 atau lebih besar dari 5\%,, jadi tidak terdapat cukup bukti empiris untuk menerima hipotesis pertama. Hipotesis ini dapat disimpulkan bahwa struktur modal tidak berpengaruh terhadap profitabilitas, dan mempunyai arah negatif (melemahkan) yang terlihat pada nilai original sample $(\mathrm{O})$ yakni sebesar $-0,173$., sehingga secara teori sudah sesuai bahwa struktur modal mempunyai pengaruh negatif terhadap besarnya profitabilitas.

2) Pengujian hipotesis kedua, variabel $X 2$ yakni struktur kepemilikan tidak berpengaruh terhadap variabel $Y$ yakni profitabilitas, karena mempunyai nilai $P$ values sebesar 0,129 ., dimana nilai $P$ values tersebut lebih dari 0.05 atau lebih besar dari 5\%., jadi tidak terdapat cukup bukti empiris untuk menerima hipotesis kedua. Hipotesis ini dapat disimpulkan bahwa struktur kepemilikan tidak berpengaruh terhadap profitabilitas, tetapi mempunyai arah yang positif (menguatkan) yang terlihat pada nilai original sample $(\mathrm{O})$ yakni sebesar 1,281 ., sehingga secara teori sudah sesuai bahwa struktur kepemilikan mempunyai pengaruh positif terhadap besarnya profitabilitas.

3) Pengujian hipotesis ketiga, variabel $X 3$ yakni faktor teknikal tidak berpengaruh terhadap variabel $Y$ yakni profitabilitas, karena mempunyai nilai $\mathrm{P}$ values sebesar 0,143., dimana nilai $\mathrm{P}$ values tersebut lebih dari 0.05 atau lebih besar dari 5\%., Jadi tidak terdapat cukup bukti empiris untuk menerima hipotesis ketiga. Hipotesis ini dapat 
disimpulkan bahwa faktor teknikal tidak berpengaruh terhadap profitabilitas, tetapi mempunyai arah yang positif (menguatkan) yang terlihat pada nilai original sample (O) yakni sebesar 0,206. sehingga secara teori sudah sesuai bahwa faktor teknikal mempunyai pengaruh positif terhadap besarnya profitabilitas.

4) Pengujian hipotesis keempat, dimana variabel moderasi $Z$ yakni total pendapatan berpengaruh terhadap variabel $\mathrm{Y}$ yakni profitabilitas, karena mempunyai nilai $\mathrm{P}$ values sebesar 0,032 ., dimana nilai $\mathrm{P}$ values tersebut kurang dari 0,05 atau kurang dari 5\%. Variabel moderating effect 1 (ME 1), tidak berpengaruh terhadap variabel Y yakni profitabilitas, karena mempunyai nilai $\mathrm{P}$ values sebesar 0,763 , atau sebesar $76,3 \%$, dimana nilai $\mathrm{P}$ values tersebut lebih besar dari 0.05 atau lebih dari 5\%., dengan demikian disimpulkan bahwa variabel $\mathrm{Z}$ yakni total pendapatan tidak mampu memoderasi hubungan antara variabel X1 yakni struktur modal dengan variabel Y yakni profitabilitas, dengan arah positif (menguatkan) seperti terlihat pada nilai original sample (O) sebesar 0,092., Hipotesis ini dapat disimpulkan tidak terdapat cukup bukti empiris untuk menerima hipotesis keempat atau hipotesis ditolak.

5) Pengujian hipotesis kelima, dimana variabel moderasi $Z$ yakni total pendapatan berpengaruh terhadap variabel $Y$ yakni profitabilitas, karena mempunyai nilai $\mathrm{P}$ values sebesar 0,032 ., dimana nilai $\mathrm{P}$ values tersebut kurang dari 0,05 atau kurang dari 5\%., Variabel moderating effect 2 (ME 2) tidak berpengaruh terhadap variabel Y yakni profitabilitas, karena mempunyai nilai $\mathrm{P}$ values sebesar 0,086 ., atau sebesar $8,6 \%$, dimana nilai $\mathrm{P}$ values tersebut lebih besar dari 0.05 atau lebih besar dari 5\%,, dengan demikian disimpulkan bahwa variabel $\mathrm{Z}$ yakni total pendapatan tidak mampu memoderasi hubungan antara variabel $\mathrm{X} 2$ yakni struktur kepemilikan dengan variabel $\mathrm{Y}$ yakni profitabilitas dengan arah positif (menguatkan) seperti terlihat pada nilai original sample (O) sebesar 2,271. Hipotesis ini dapat disimpulkan tidak terdapat cukup bukti empiris untuk menerima hipotesis kelima atau hipotesis ditolak.

6) Pengujian hipotesis keenam, dimana variabel moderasi $\mathrm{Z}$ yakni total pendapatan berpengaruh terhadap variabel $\mathrm{Y}$ yakni profitabilitas, karena mempunyai nilai $\mathrm{P}$ values sebesar 0,032 ., dimana nilai $\mathrm{P}$ values tersebut kurang dari 0,05 atau kurang dari 5\%. Variabel moderating effect 3 (ME 3) tidak berpengaruh terhadap variabel Y yakni profitabilitas, karena mempunyai nilai $\mathrm{P}$ values sebesar 0,935., atau sebesar 93,5\%, dimana nilai $\mathrm{P}$ values tersebut lebih besar dari 0.05 atau lebih besar dari 5\%., dengan demikian disimpulkan bahwa variabel $\mathrm{Z}$ yakni total pendapatan tidak mampu memoderasi hubungan antara variabel X3 yakni faktor teknikal dengan variabel $\mathrm{Y}$ yakni profitabilitas dengan arah positif (menguatkan) seperti terlihat pada nilai original sample $(\mathrm{O})$ sebesar 0,022., Hipotesis ini dapat disimpulkan tidak terdapat cukup bukti empiris untuk menerima hipotesis keenam atau hipotesis ditolak.

\section{Simpulan}

Penelitian ini diperoleh berdasarkan analisis terhadap hasil penelitian telah dijelaskan pada bab sebelumnya, maka dapat ditarik kesimpulan yaitu:

1. Struktur modal tidak berpengaruh terhadap profitabilitas, dan mempunyai arah negatif (melemahkan).

2. Struktur kepemilikan tidak berpengaruh terhadap profitabilitas, tetapi mempunyai arah yang positif (menguatkan)

3. Faktor teknikal tidak berpengaruh terhadap profitabilitas, tetapi mempunyai arah yang positif (menguatkan)

4. Variabel $\mathrm{Z}$ yakni total pendapatan tidak mampu memoderasi hubungan antara variabel X1 yakni struktur modal terhadap variabel $Y$ yakni profitabilitas, dengan arah positif (menguatkan).

5. Variabel $\mathrm{Z}$ yakni total pendapatan tidak mampu memoderasi hubungan antara variabel X2 yakni struktur kepemilikan terhadap variabel Y yakni profitabilitas dengan arah positif (menguatkan).

6. variabel $\mathrm{Z}$ yakni total pendapatan tidak mampu memoderasi hubungan antara variabel $\mathrm{X} 3$ yakni faktor teknikal terhadap variabel Y yakni profitabilitas dengan arah positif (menguatkan)

\section{Daftar Pustaka}

Adisetiawan, R., Yunan Surono, 2016, Indonesia Capital Market Efficiency, British Journal of Economics, Finance and Management Sciences, 11(1), 108-121

Adisetiawan, R., Atikah, 2018, Does Stock Split Influence to Liquidity and Stock Return? (Emoirical Evidence in The Indonesia Capital Market), Asian Economic and Financial Review, 8(5), 682-690

Ghozali, Imam. 2013. Aplikasi Analisis Multivariate dengan Program IBM SPSS 21 Update PLS Regresi. Semarang: Badan Penerbit Universitas Diponegoro.

Halim, Hidayat, 2000, Studi Empiris Tentang Pengaruh Volume Perdagangan Dan Return Terhadap Bid-Ask Spread Saham Industri Rokok di BEJ Dengan Model Korelasi Kesalahan, Jurnal Riset Akuntansi Indonesia, Vol 3, hal 69-85.

Haryono, Siswoyo. 2017. Metode SEM Untuk Penelitian Manajemen AMOS LISREL PLS. Cetakan 1. Jakarta : Luxima Metro Medi. 
Yunan Surono et al, Pengaruh Struktur Modal, Struktur Kepemilikan, Faktor Teknikal Terhadap Profitabilitas dengan Total Pendapatan Sebagai Variabel Moderasi Pada Sub Sektor Perkebunan Di Bursa Efek Indonesia Periode 2015-2018

Kasmir, 2014, Analisis Laporan Keuangan, Edisi Satu. Cetakan ketujuh. Jakarta: PT Raja Grafindo Perkasa.

Saidi. 2004. Faktor-faktor yang Mempengaruhi Struktur Modal pada Perusahaan Manufaktur Go-Pubic di BEJ Tahun 1997-2002. Jurnal Bisnis dan Ekonomi, 11 (1): 44-58.

Silviyani. 2014. Pengaruh Likuiditas Perdagangan Saham dan Kapitalisasi Pasar Terhadap Return Saham Perusahaan Yang Berada Pada Indeks LQ45 Di Bursa Efek Indonesia Periode Tahun 2009-2013 (Studi Empiris Pada Perusahaan LQ45 Di Bursa Efek Indonesia). e-Journal S1 Ak Universitas Pendidikan Ganesha Jurusan Akuntansi SI.(Volume: 2 No. 1.)

Yamin, Sofyan. 2011, Generasi Baru Mengolah Data Penelitian Dengan Partial Least Square Path Modelling. Jakarta, Salemba Infotek. 